CoOper, P. D. (1955). J. gen. Microbiol. 12, 100-106.

\title{
The Site of Action of Penicillin: some Properties of the Penicillin-binding Component of Staphylococcus aureus
}

\author{
BY P. D. COOPER \\ Wright-Fleming Institute of Microbiology, St Mary's Hospital \\ Medical School, Paddington, London, W. 2
}

SUMMARY: The penicillin-binding component (PBC) of Staphylococcus aureus is rapidly inactivated by acid but is more stable at neutral or alkaline $\mathrm{pH}$ values. At $2^{\circ}$ various preparations lost $25-50 \%$ activity overnight at the optimum pH. Cellfree preparations of $\mathrm{PBC}$ (penicillin-binding cell walls or 'lipid particles') showed an initial increase in the amount of $\mathrm{PBC}$ available to penicillin. PBC was heat-labile, being completely destroyed by $5 \mathrm{~min}$. at $50^{\circ}$. The final amount of penicillin bound did not vary over the range $\mathrm{pH} 4 \cdot 4-7 \cdot 6$, but the rate of binding was somewhat greater at the lower end of this range. No separation of $\mathrm{PBC}$ from lipid particles was achieved by several mild techniques. Organic solvents which did not remove lipid material from intact cells also failed to affect $\mathrm{PBC}$; more drastic solvent procedures which were effective in removing lipid appeared to destroy PBC. Intact cells or lipid particles from a penicillin-resistant yeast did not bind penicillin.

The most likely interpretation of the experimental finding (Rowley, Cooper, Roberts \& Lester Smith, 1950) that penicillin-sensitive cells were able to bind a small definite amount of penicillin in a specific and irreversible manner was that they contained a small amount of a chemical entity which was termed the penicillin-binding component (PBC). It was thought that $\mathrm{PBC}$ was likely to be the initial site of action of penicillin, although direct proof of this could not be afforded. PBC might exist in the cell as an easily removable co-factor or it might be an integral part of a large molecule, and its isolation would then involve the difficult task of separating a very small amount of material from a large amount of similarly constituted impurities. Alternatively, it is theoretically possible that PBC cannot exist separately, but is rather a steric effect produced by the conjunction of two large molecules between which the penicillin happens to fit. Any attempt to separate the two large molecules would then lead to the disappearance of PBC. Nevertheless, it seemed worth while to attempt the preparation of $\mathrm{PBC}$ in a soluble form from which chemical purification could begin. The results given below describe some properties of PBC and the lipid-containing particulate fraction in which it is concentrated (Cooper, 1954), and illustrate some of the difficulties encountered in obtaining $\mathrm{PBC}$ in soluble form.

\section{METHODS}

Uptake of radiopenicillin by intact cells was measured by the method described by Rowley et al. (1950), and the preparation of, and measurement of uptake by, penicillin-binding cell walls were as described by Few, Cooper \& Rowley (1952). Methods of growing the staphylococcus used, preparation of 'lipid particles' and measurement of penicillin-binding by lipid particles by 
use of radiopenicillin and by bioassay were described by Cooper (1954). The radiopenicillin purity was checked by methods described by Cooper, Clowes \& Rowley (1954).

\section{RESULTS}

\section{Stability of penicillin-binding component}

It was important to know to which experimental conditions PBC could be submitted without undue loss. The results illustrated in Fig. 1 show that PBC could be kept at neutral or alkaline $\mathrm{pH}$ values for several hours at room temperature even in the cell-free state, but was rapidly and irreversibly inactivated by acid. About $25 \%$ of the PBC was lost from intact cells when kept

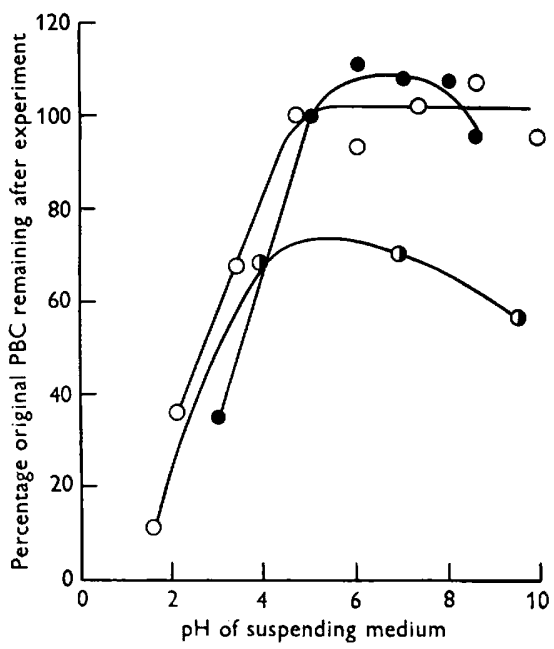

Fig. 1

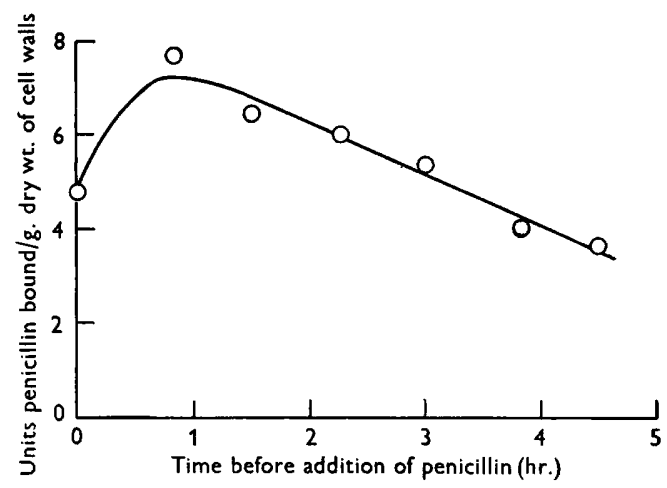

Fig. 2

Fig. 1. Effect of $\mathrm{pH}$ value on stability of $\mathrm{PBC}$ in $0 \cdot 1 \mathrm{M}$-phosphate $+0 \cdot 1$ M-acetate. Assays of the initial activity were made separately in each case. $0-0$, intact cells, left for $16 \mathrm{hr}$. at various $\mathrm{pH}$ values and $2^{\circ}$, washed 3 times and adjusted to $\mathrm{pH} 7$ before addition of radiopenicillin. - cell walls prepared in formalin mixture left for $45 \mathrm{~min}$. at various $\mathrm{pH}$ values and $24^{\circ}$, washed twice and adjusted to $\mathrm{pH} \mathrm{z}$ before addition of radiopenicillin. $\mathrm{O}-\mathrm{O}$, unwashed lipid particles, left for $90 \mathrm{~min}$. at various $\mathrm{pH}$ values and $24^{\circ}$, neutralized by addition of penicillin in an equal vol. 2 M-phosphate buffer at $\mathrm{pH} 7 \cdot 5$; binding determined biologically by cup-plate assay of residual unbound penicillin.

Fig. 2. Effect of time of standing in distilled water at $18^{\circ}$ on the penicillin-binding capacity of cell walls prepared in formalin mixture. Radiopenicillin was added at various times, and the suspensions then kept in the cold until the end of the experiment, when all were centrifuged and washed together for ${ }^{35} \mathrm{~S}$ assay.

overnight at $2^{\circ}$ at the optimum $\mathrm{pH}$ value ( $\mathrm{pH}$ 6). In one sample of lipid particles stored overnight at $2^{\circ}$ in the presence of cell cytoplasm about $50 \%$ of the initial PBC was lost. The curious suggestion (in Fig. 1) that the penicillinbinding ability of cell walls prepared in formalin (Few et al. 1952) had increased slightly during the course of the experiment was confirmed in several experiments; it always occurred during the 1-2 hr. following the completion of the formalin cell-wall preparation and then fell fairly rapidly (Fig. 2). A similar 
increase in available PBC but without subsequent rapid loss also occurred with lipid particles which had been separated from the cytoplasmic supernatant; it proceeded at about the same rate at $0^{\circ}$ as at $37^{\circ}$ (Tables 1 and 2). This, with the lack of inhibition of the effect by formalin pretreatment, suggested that the increase was not enzymic. Approximately twice as much PBC is liberated on cell rupture as is available to the penicillin in the intact cell (Cooper, 1954). The final uptake reached in Table 1 corresponds closely with the uptake by lipid particles when inactivation of $\mathrm{PBC}$ during rupture is minimized by shaking in the presence of radiopenicillin. The ability of the lipid particles to regain their penicillin-binding capacity on standing suggests that this inactivation may be reversible.

\section{Table 1. Stability of $P B C$ in unwashed lipid particle suspensions in distilled water at $0^{\circ}$ and $37^{\circ}$}

At the beginning of the experiment about $2 \mathrm{hr}$. had elapsed from start of cell rupture. Penicillin was added $\left(0.07 \mathrm{unit} / \mathrm{ml}\right.$.) at various times and the suspensions then kept at $0^{\circ}$ until the end of the experiment. The residual penicillin concentrations were determined by bioassay.

$\begin{array}{ccccc}\text { Time of observation } & \begin{array}{c}\text { Amount of penicilin bound by } \\ \text { particle suspension (unit/ml.) }\end{array} & \overbrace{}^{\circ} & \overbrace{0}^{\circ} & \begin{array}{c}\text { Penicillin bound by lipid } \\ \text { particles (unit/g. dry wt. } \\ \text { particles) }\end{array} \\ 0 & 0 \cdot 008 & 0 \cdot 008 & 6 \cdot 4 & 37^{\circ} \\ 1 \frac{1}{2} & 0 \cdot 031 & 0 \cdot 041 & 25 & 6 \cdot 4 \\ 2 & 0 \cdot 036 & 0 \cdot 028 & 29 & 22 \\ 3 & 0 \cdot 040 & 0 \cdot 032 & 32 & 25\end{array}$

Table 2. Effect of temperature on stability of $P B C$

Experimental method as in Table 1.

Amount of penicillin bound by lipid particle suspension (unit/ml.)

\begin{tabular}{|c|c|c|c|c|c|c|c|c|}
\hline \multirow[t]{2}{*}{ Initially } & \multicolumn{3}{|c|}{ After $3 \frac{1}{4} \mathrm{hr}$. at } & \multicolumn{5}{|c|}{ After 5 min. at } \\
\hline & $0^{\circ}$ & $24^{\circ}$ & $37^{\circ}$ & $40^{\circ}$ & $50^{\circ}$ & $\mathbf{5 6}^{\circ}$ & $60^{\circ}$ & $90^{\circ}$ \\
\hline 0.031 & $0 \cdot 021$ & 0.018 & 0.014 & - & - & $<0.003$ & - & $<0.003$ \\
\hline 0.015 & - & $\ldots$ & - & 0.011 & $<0.004$ & $\ldots$ & $<0.004$ & $\ldots$ \\
\hline
\end{tabular}

The apparent difference in rates of loss of $\mathrm{PBC}$ from penicillin-binding cell walls and from lipid particles is probably due to the several washes of the former involved in the assay of bound penicillin. Thus PBC may become progressively more easily washed away from cell walls on standing.

$\mathrm{PBC}$ was unstable at higher temperatures, none being detectable after $5 \mathrm{~min}$. at $50^{\circ}$ (Table 2). Freeze-drying had no effect on the PBC content of intact cells, lipid particles or formalin-prepared cell walls. The PBC-radiopenicillin complex remained attached to intact cells in aqueous suspension very much longer than PBC itself was detectable. 


\section{Effect of $\mathrm{pH}$ value on penicillin uptake}

Fig. 3 shows that the final amount of penicillin bound by resting cells ( 20 min. total contact) was only a little affected between $\mathrm{pH} 4 \cdot 4$ and $7 \cdot 6$. Very similar curves were obtained when the penicillin solutions were adjusted to the various $\mathrm{pH}$ values for the same period of time and neutralized before addition of cells, showing that the higher uptakes at $\mathrm{pH} 3$ and $\mathbf{4 \cdot 4}$ were entirely due to radio-active decomposition products of penicillin. The lowest $\mathrm{pH}$ value at which instability of penicillin is small over the course of the experiment is about $\mathrm{pH} \mathbf{4} \cdot \mathbf{4}$ (Brodersen, 1947), increasing greatly at lower $\mathrm{pH}$ values. However, although the final amount of uptake of radiopenicillin is independent of $\mathrm{pH}$, the rate at which this value is attained is decreased with increase in $\mathrm{pH}$ value (Fig. 4). The effect of $\mathrm{pH}$ value on the rate of penicillin uptake is of interest in view of reports (Abraham \& Duthie, 1946; Eagle, Levy \& Fleischman, 1952) which indicated that penicillin is considerably more active at $\mathrm{pH} 6$ than at $\mathrm{pH} 7 \cdot 5$. Since the minimal inhibitory titre may be the result of a balance between the rate of inactivation of $\mathrm{PBC}$ by penicillin and the rate of $\mathrm{PBC}$ resynthesis (Maass \& Johnson, 1949b), any increase in the rate of inactivation of $\mathrm{PBC}$ caused by $\mathrm{pH}$ changes should result in this balance being struck at lower titres, since the rates of penicillin-binding at $\mathrm{pH} 5.5$ and $\mathbf{7 \cdot 3}$ are roughly proportional to penicillin concentration (Fig. 5 ). It can be calculated from Figs. 4 and 5 that penicillin at $0.025 \mathrm{unit} / \mathrm{ml}$. and $\mathrm{pH} 7.5$ should inactivate $\mathrm{PBC}$ as fast as at $0.017 \mathrm{unit} / \mathrm{ml}$. and $\mathrm{pH} 6 \cdot 0$. The difference between these theoretical minimal inhibition concentrations is rather less than the two- or fourfold differences observed by Abraham \& Duthie and by Eagle and colleagues over this $\mathrm{pH}$ range, so that changes in penicillin binding-rate are probably not the only effects of $\mathrm{pH}$ value on the lethal process caused by penicillin.

\section{Some properties of the lipid particles}

The lipid particle suspension could not be fractionated by any of several mild methods. Electrophoresis at $\mathrm{pH} 9 \cdot 0,7 \cdot 4$ and 6.0 gave single ascending and descending boundaries which became less distinct with time and rapidly moved at different rates towards the anode, suggesting a polydisperse system bearing a negative charge. $\mathrm{PBC}$ remained in the fast-moving fraction. The $\mathrm{pH}$ value of maximum precipitation (iso-electric point?) was between $\mathrm{pH} 3$ and 4, so that fractional precipitation at lower $\mathrm{pH}$ values would involve too much loss of PBC to be practicable. Differential centrifugation of lipid particles over the range $8000-16,000 \mathrm{~g}$ produced no changes in the $\mathrm{PBC}$ or lipid $\mathrm{P}$ assays. A fairly constant amount of lipid particle was soluble in each ml. of distilled water but the saturated solution was too dilute to produce a visible boundary in the electrophoresis apparatus. Both lipid particles and PBC were completely precipitated by calcium ions and by freezing and thawing, but were unaltered in appearance by boiling. A preparation of Clostridium welchii $\alpha$-toxin (containing the lecithinase $\mathrm{C}$ ) in $0.01 \mathrm{M}-\mathrm{CaCl}_{2}$, or $1 \mathrm{mg}$. crystalline ribonuclease or trypsin per $\mathrm{ml}$. at $37^{\circ}$ for $30 \mathrm{~min}$. had no effect on $\mathrm{PBC}$ or on the lipid particles. 


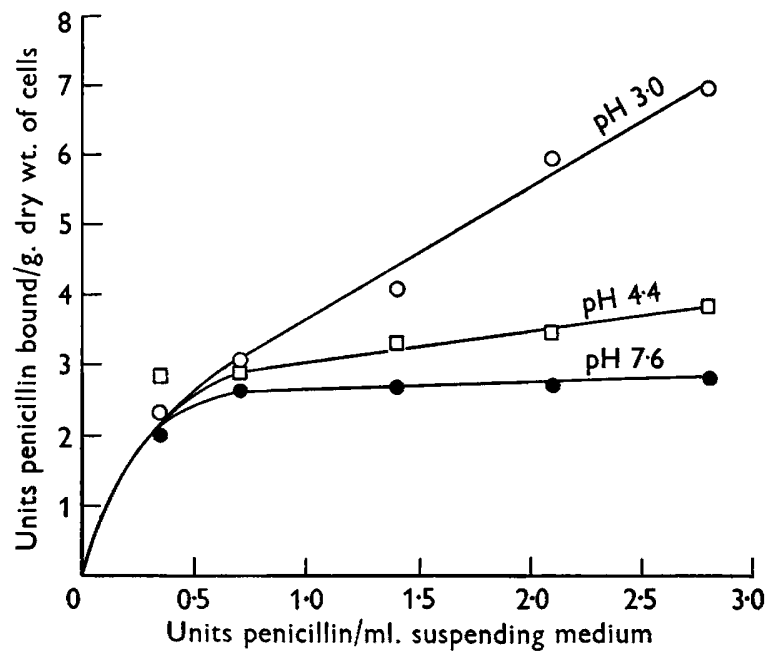

Fig. 3. Effect of $\mathrm{pH}$ value on the uptake of radiopenicillin on intact cells suspended at $5 \mathrm{mg}$. dry wt. $/ \mathrm{ml}$. in $0 \cdot 1 \mathrm{M}$-phosphate $+0 \cdot 1$ M-acetate. Three samples of cells were adjusted to $\mathrm{pH}$ values of $3 \cdot 0,4 \cdot 4,7 \cdot 6$ respectively, each sample was divided into five portions and differing concentrations of radiopenicillin was added to each portion. After $15 \mathrm{~min}$. at $18^{\circ}$ the cells were rapidly centrifuged and washed 3 times in water for ${ }^{35} \mathrm{~S}$ assay.

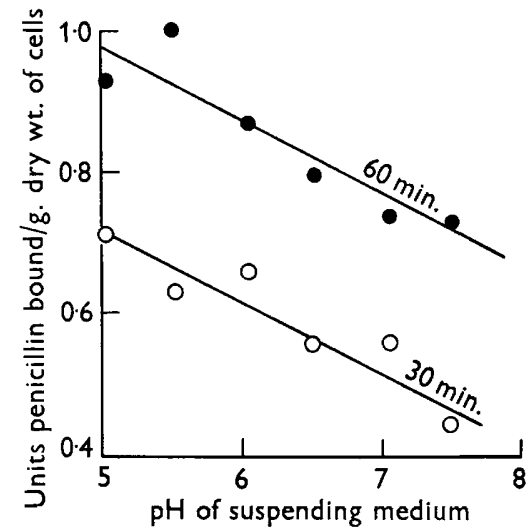

Fig. 4

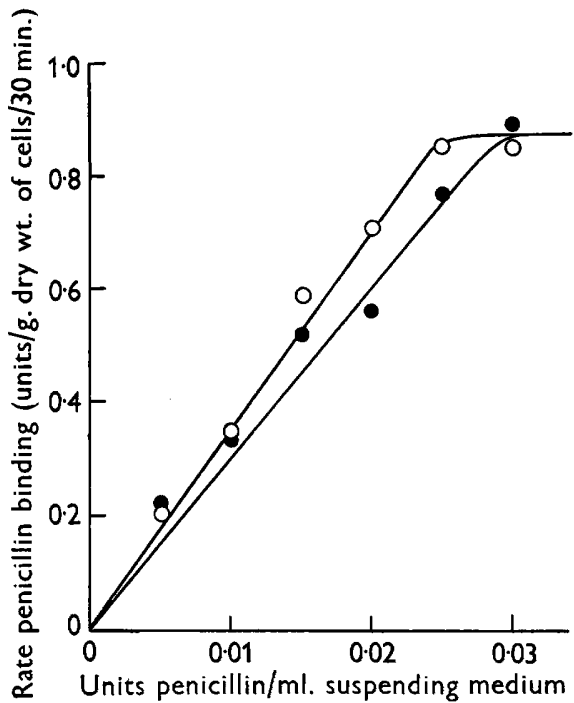

Fig. 5

Fig. 4. Effect of pH on rate of penicillin uptake. Six samples of cells were adjusted to various pH values in $0 \cdot 1 \mathrm{M}$-phosphate $+0.1 \mathrm{~m}$-acetate and radiopenicillin was added to 0.02 u./ml. at zero time. Half of each sample was rapidly centrifuged and washed after $30 \mathrm{~min}$. at $18^{\circ}(\mathrm{O}-\mathrm{O})$, and the remainder after $60 \mathrm{~min}$. ( - - , for ${ }^{35} \mathrm{~S}$ assay.

Fig. 5. Effect of penicillin concentration on rate of uptake at $\mathrm{pH} 5 \cdot 53(\mathrm{O}-\mathrm{O})$ and $\mathrm{pH} \mathrm{7 \cdot 35}$ (-). Cells were suspended in $0.1 \mathrm{M}$-phosphate $+0.1 \mathrm{~m}$-acetate, the suspensions were adjusted to $\mathrm{pH} \mathrm{5.53}$ or $\mathrm{pH} 7 \cdot 35$ and added to the prepared radiopenicillin dilutions. After $30 \mathrm{~min}$. at $18^{\circ}$ the samples were centrifuged rapidly and washed for ${ }^{35} \mathrm{~S}$ assay. 


\section{Attempts to extract $P B C$ from intact cells}

At room temperature addition of ethanol, $5 \%$ ethanol, ethyl ether, chloroform, acetone, $5 \%$ phosphate $(\mathrm{pH} 9 \cdot 0), 9 \%$ urea or $10 \% \mathrm{NaCl}$ solutions to freeze-dried cells did not remove PBC; nor did adjustment of a thick cell

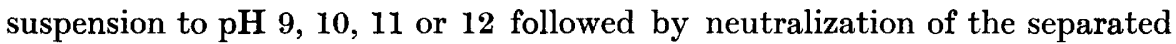
extracts. Under these conditions, the organic solvents mentioned were also ineffective in removing lipid. Trichloroacetic acid $(10 \%, w / v)$, anhydrous formic acid, anhydrous pyridine, cyclohexylamine, $90 \%$ phenol, hot methanol and anhydrous diethylene glycol rendered the cells incapable of irreversibly binding radiopenicillin, but no $\mathrm{PBC}$ (by bioassay; or by electrodialysis assay method, Few, Cooper \& Rowley, 1953) was detected in the residues from extracts made with trichloroacetic or formic acids, cyclohexylamine, pyridine or $90 \%$ phenol (dialysed or freeze-dried to remove solvent), with diethylene glycol (dialysed or ethanol-precipitated) or with hot methanol (distilled off in vacuo).

Treatment with $90 \%$ phenol, followed by cold acetone and ether, did not extract any ${ }^{35} \mathrm{~S}$ from cells grown in radiopenicillin and washed thoroughly, although all the lipid and lipid $\mathbf{P}$ was extracted. This suggests that the penicillin did not react with the lipid fraction of the lipid particles, although any solvent procedures which succeeded in extracting cell lipid (90\% phenol, pyridine, hot methanol, cyclohexylamine) also succeeded in destroying PBC.

\section{Uptake of penicillin by yeast}

The findings of Maass \& Johnson (1949a) that penicillin was not bound by yeast have been confirmed in this laboratory with a strain of baker's yeast. Daniel \& Johnson (1954) showed that cell-free extracts of Saccharomyces carlsbergensis bound penicillin in an apparently specific manner, but radiopenicillin uptake experiments in the present work did not reveal any irreversible binding of penicillin by the lipid particles of the baker's yeast used (i.e. less than $0 \cdot 1$ unit penicillin at $0.4 \mathrm{unit} / \mathrm{ml}$.). Perhaps yeast species contain PBC within the cell and sheltered from penicillin, rather than at or near the surface as in Staphylococcus aureus. It is interesting that briefly heating the supernatant from centrifuged ruptured staphylococcal cell suspensions appears to destroy the 'reversible' binding by cell contents (Daniel \& Johnson, 1954; Cooper, 1954).

\section{DISCUSSION}

It can be seen that considerable difficulties are involved in the separation of $\mathbf{P B C}$ in a chemically definable form. All attempts to prepare a soluble extract were unsuccessful except for a simple saturated solution of lipid particles which was rather dilute to handle chemically or electrophoretically. Attempts to concentrate this solution produced coagulation on freeze-drying or inactivation by heat. $\mathrm{PBC}$ is very unstable to heat and acid, and cannot be kept long even at low temperature and at the optimum $\mathrm{pH}$. Accordingly, extraction procedures must not be used which require prolonged standing in the presence of water, e.g. dialysis or solvent precipitation. 
The so-called 'lipid particles' contain a large amount of protein (Mitchell \& Moyle, 1951) as well as about $20 \%$ of lipid material and PBC, and their behaviour as outlined above indicates their chemical constitution to include a sparingly soluble lipo-protein complex in which the fatty material is strongly bound. PBC also appears to be strongly bound, but it may be more closely connected with the protein part. This is perhaps to be expected if penicillin specifically interferes with some enzymic activity, although binding is not affected by trypsin. Daniel \& Johnson (1954) also found that their PBC was not affected by trypsin. The effect of trypsin may thus be a useful method of distinguishing the specific binding by PBC from the non-specific binding present in supernatants from ruptured cell suspensions (Cooper, 1954).

I should like to thank Dr D. Rowley for his helpful criticism, advice and support. I wish to acknowledge a grant from London University Central Research Fund for apparatus.

\section{REFERENCES}

Abraham, E. P. \& DUthie, E. S. (1946). Effect of pH of the medium on activity of streptomycin and penicillin and other chemotherapeutic substances. Lancet, i, 455.

Brodersen, R. (1947). Stability of penicillin $G$ in aqueous solution as a function of hydrogen-ion concentration and temperature. Acta pharm. tox., Kbh. 3, 345.

Cooper, P. D. (1954). The association of the penicillin-binding component of Staphylococcus aureus with a lipid fraction. J. gen. Microbiol. 10, 236.

Cooper, P. D., Clowes, R. C. \& Rowley, D. (1954). A note on the use of radioactive penicillin. J. gen. Microbiol. 10, 246.

Daniel, J. W. \& Johnson, M. J. (1954). Properties of the penicillin-binding component of Micrococcus pyogenes. J. Bact. 67, 321.

Eagle, H., Levy, M. \& Fleischman, R. (1952). Effect of pH on the antibacterial activity of penicillin, streptomycin, chloramphenicol, terramycin and bacitracin. Antibiotics \& Chemotherapy, $2,563$.

Few, A. V., Cooper, P. D. \& Rowley, D. (1952). Reaction of penicillin with the staphylococcal cell wall. Nature, Lond. 169, 283.

Few, A. V., Cooper, P. D. \& Rowley, D. (1953). Determination of radio-penicillin uptake by electrodialysis. Biochem. J. 53, xix.

MaAss, E. A. \& Johnson, M. J. (1949a). Penicillin uptake by bacterial cells. J. Bact. $57,415$.

MAAss, E. A. \& Johnson, M. J. (1949b). The relations between bound penicillin and growth in Staphylococcus aureus. J. Bact. 58, 361.

Mitchell, P. \& Moyle, J. (1951). 'The glycerophospho-protein complex envelope of Micrococcus pyogenes. J. gen. Microbiol. 5, 981.

Rowley, D., Cooper, P. D., Roberts, P. W. \& Lester Smith, E. (1950). The site of action of penicillin. 1. Uptake of penicillin on bacteria. Biochem. J. 46, 157. 